Izvorni znanstveni rad DOI: $10.17234 /$ Croatica.41.8 UDK: 821.163.42-13.09Gundulić, I. 821.163.42-2.09Mrnavić, T.

\title{
. \\ EMOCIONALNI SVIJET OSMANA I OSMANŠĆICE
}

\author{
Amir Kapetanović \\ Institut za hrvatski jezik i jezikoslovlje \\ akapetan@ihjj.hr
}

U prilogu se opisuje i uspoređuje iskazivanje i poimanje nekih "osnovnih" emocija u Gundulićevu Osmanu i Mrnavićevoj Osmanšćici, dvama baroknim tekstovima hrvatske književnosti koji tematiziraju život, vlast i smrt sultana Osmana II. I u dramskom i u epskom svijetu tih tekstova emocije su važna sastavnica tekstnoga tkiva. Posebna pozornost posvećuje se povezivanju diskursa o emocijama s određenim metaforičkim konceptima (srdžbe, straha, tuge, radosti, ljubavi i mržnje), stereotipnim poimanjima i konvencionalnom leksiku uzimajući pritom u obzir i različitost perspektiva tih pisaca (Gundulićevo zauzimanje kršćanske i Mrnavićevo zauzimanje osmanlijske perspektive) koje proizvode određene razlike u iskazivanju emocija. Oba teksta proučavala je pomno prof. Fališevac i napisala o tim tekstovima važne priloge, pa će se odabrana tema pokušati osvijetliti u ovom radu na njezinu stručnom tragu.

Ključne riječi: emocije, I. Gundulić, I. T. Mrnavić, Osman II, ep, drama, hrvatski jezik i književnost, 17. stoljeće

1.1. Hrvatske pisce Ivana Gundulića (1589-1638) i Ivana Tomka Mrnavića (1580-1637) povezuje književno tematiziranje događaja vezanih uz život i smrt sultana Osmana II. (1604-1622) koji je, navršivši četrnaest godina, svrgnuo s prijestolja psihički oboljela strica Mustafu. Događaje u vezi s 
prvom osmanlijsko-poljskom bitkom kod Hoćima/Hotina (1621) i pobunom janjičara te Osmanovom smrću, uz mnoge nepovijesne fabularne ekstenzije (integrirajuća putovanja i susreti), Dubrovčanin Gundulić obradio je u epu Osman (u zadnjem desetljeću života 1628-1638), a carigradske događaje iz istih godina Šibenčanin Mrnavić u petočinoj drami Osmanšćica (dovršenoj godinu dana prije tiska 1631). ${ }^{1}$ Oba djela u hrvatsku književnost uvode neke novine: tragedija Osmanšćica smatra se povijesnom (i prvom originalnom senekijanskom hrvatskom) dramom koja tematizira suvremeni događaj (Fališevac 2003: 43), a Gundulićev je ep "strukturiran ne samo kao ep baroknog slavizma i ep katoličke obnove, ne samo kao vergilijanski i viteško-romantični epski svijet, nego i kao povijesni ep, s naglašenom aktualizacijom i politizacijom suvremena svijeta - i to temom građanskog rata" (Fališevac 1997: 159) i slijedi Tassovu koncepciju epa s razuđenom složenom kompozicijom, što obuhvaća, zahvaljujući sekundarnim fabularnim linijama, potpuniji epski svijet nego u dotadašnjim epovima pravocrtne kompozicije. Uz to Osman sadržava i eshatološke motive iz pakla, što se doimaju kao neka vrsta "slijepe ulice u kompozicijskom nacrtu epa" (Kravar 1993: 119). Iako Gundulićev pripovjedač događaje daje iz kršćanske perspektive s likovima iz kršćanskoga i muslimanskoga svijeta, pripovjedač gleda na carigradska zbivanja dubrovačkim očima (Rapacka 1998: 157) i iz plemićke vizure zastupa stajališta u vezi s očuvanjem vlasti, što ih predstavlja Osman, a njegovo stradanje Gundulić tematizira, između ostaloga, vjerojatno i zato što je tada u dva tabora podijeljenom dubrovačkom patricijatu "htio pokazati što se događa kad opasnost dođe iznutra, a ne izvana" (Tatarin 2015). Mrnavić je u svojoj drami događaje dao isključivo iz očišta likova koji pripadaju samo muslimanskom svijetu i nije ugrađivao, "objektivnosti"2 težeći, "nikakve ideologeme vladajuće ili željene slike svijeta, a ni na jednom mjestu ne oblikuje lik koji bi bio glasnogovornik piščevih stavova, težnji ili koncepcija" (Fališevac 2003: 44), što bi se moglo reći za Gundulićeva Osmana. ${ }^{3}$ D.

\footnotetext{
Nisu samo I. Gundulić i I. T. Mrnavić tematizirali taj događaj, sačuvan je i fragment pjesme Pripovijes od Osmana u osmeračkim katrenima iz pera O. Mažibradića (v. Fancev 1933/34,v. Tatarin 2015).

2 Takav dojam ostavlja Mrnavićeva drama od 19. st., npr. Kukuljević Sakcinski rekao je da, u usporedbi s Osmanom, Osmanšćica "slikuje povjest onoga vremena istinitije, a Turke onako, kakovi su doista bili” (Kukuljević Sakcinski 1868: 250).

3 Dva teksta nemaju podjednaku stručnu recepciju u hrvatskoj filologiji - dok su Gundulićevu Osmanu posvećene knjige (npr. Pavličić 1996) i sveukupnu stručnu literaturu o tom epu teško
} 
Fališevac, istaknuta hrvatska povjesničarka hrvatske književnosti, koja je i o epskom svijetu Osmana i o dramskom svijetu Osmanšćice napisala mnogo zapaženih i u filologiji nezaobilaznih redaka, ističe da je Osmanšćica tekst "koji je prije bio namijenjen čitanju nego izvođenju" i drama

[n]eopremljena bilo kakvim didaskalijama, s dugim monološkim partijama, oskudna u dramskom zapletu koji na ishod dramske radnje nema nikakva djelovanja [...], u njoj nema nikakvih ljubavnih zapleta, korski dijelovi kao i sekvence u kojima se pjeva i pleše [...] vrlo su rijetki [...], naznaka o izgledu pozornice u drami nema (Fališevac 2003: 33).

Za tekstno tkivo Osmanšćice značajna je epska naracija u dugim dramskim replikama. I Gundulić unosi u Osmana značajke drugih književnih žanrova kao što su elementi ljubavne lirike, religiozno-refleksivne poezije, pastoralnih žanrova, putopisa, usmene i pučke pjesme (Fališevac 2007: 242).

1.2. U ovom prilogu $u^{4}$ usredotočit ćemo se uglavnom na one emocije ${ }^{5}$ koje većina istraživača smatra osnovnima (tuga, strah, srdžba, radost) i na dvije koje se smatraju složenim (sekundardnim) emocijama ([romantična] ljubav, mržnja). ${ }^{6}$ Te su četiri osnovne emocije izabrane za analizu jer su one ne samo važni "alati" u oblikovanju mnogih književnih tekstova nego i emocije najpodrobnije opisane u njima. Od tzv. složenih emocija za analizu su izabrane dvije suprotstavljene, koje književni tekstovi teško zaobilaze. Za

bi ovdje bilo prikazati i u sažetu bibliografskom obliku, Osmanšćica je, možda zato što nije do danas u suvremenoj transkripciji objavljena, rijetko ulazila u istraživački fokus (npr. Kukuljević 1868: 242-265, Pavić 1875, Novak 1999: 93-103, Kapetanović 2008: 89-104), a još su rjeđi bili pokušaji usporedbe dvaju tekstova (npr. Fališevac 2003: 27-47, Dukić 2004).

4 Poviješću emocija na temelju hrvatske pisane baštine bavili smo se dosad u: Kapetanović 2009, 2012, 2013.

5 Emocije smatramo spojem osjećaja, tjelesnoga očitovanja i misli, dakle, emocije i osjećaji nisu sinonimni nazivi u našem radu. Razlikovanje polazi od tumačenja iz psihologije, prema kojima su emocije konstrukti, u čijim je složenim ustrojstvima osjećaj, shvaćen kao subjektivni doživljaj, samo jedna sastavnica emocije uz "fiziološko uzbuđenje, motoričku ekspresiju, akcijsku komponentu" (Scherer 2003: 124).

6 Ne postoji suglasnost među istraživačima koje su i koliko je osnovnih emocija, ali većina istraživača među osnovne uključuje tugu, strah, srdžbu i radost. Tim emocijama kadšto se pridružuje iznenađenje i gađenje. O šest navedenih primarnih emocija piše i P. Ekman (Ekman 1970), premda je on kasnije s W. Friesenom zaključio da i prijezir treba smatrati primarnom emocijom (Ekman i Friesen 1986). O osnovnim i složenim (sekundarnim) emocijama v. npr. Petz 2003: 248-249, 256-263; Petz 2005: 68-69. 
razliku od osnovnih složene emocije teže se mogu istraživati u starim pisanim tekstovima jer je često teško razlikovati i razgraničavati očitovanja tih emocija i osjećaja (npr. razlikovanje različitih vrsta ljubavi i prisnosti, mržnje i zavisti).

Teško je sažeti sve moguće pristupe istraživanju emocija, izvan filologije i u filologiji, a nije lako ni pomiriti različite poglede na ista pitanja kao što je pitanje univerzalnosti ili kulturne specifičnosti emocija (v. o tom Wierzbicka 1999) ili dvojbe oko istraživanja emocija i njihovih protokoncepata u dalekoj prošlosti. ${ }^{7} \mathrm{U}$ ovom radu za istraživanje dvaju književnih tekstova bit ce ključna ispomoć teorije konceptualne metafore ${ }^{8}$, koja se razvija pod okriljem kognitivne lingvistike, i to ne da bismo na književnim tekstovima iskušavali ili unapređivali dosadašnje dosege na tom jezikoslovnom području, nego da bismo primijenili i upotrijebili tu teoriju za analitičke prodore u dublje slojeve književnih slojeva.

7 Naziv emocija može biti problematičan kad se istražuju tekstovi velike starine jer je pitanje koliko su naši današnji koncepti emocija podudarni s negdašnjima. Primjerice, neki istraživači (Vukoja 2012: 25-85) smatraju da je za istraživanje hrvatskoga crkvenoslavenskoga korpusa iz srednjega vijeka, kojim dominiraju religiozne teme, primjerenije slijediti Akvinčev sustav čuvstava i afekata nego modernu psihologiju emocija. No mi se ovdje priklanjamo razmišljanjima nekih povjesničara koji naziv emocija prilično uopćeno koriste kao nadređeni pojam što pokriva "afektivne reakcije svih vrsta, intenziteta i trajanja" (Rosenwein 2006: 4). O pojmu "emocionalna zajednica" (autoričin pojam) v. i u najnovijoj knjizi Rosenwein 2016, a obuhvaća vremenski raspon 600-1700. godine.

8 Ta se teorija razvija u posljednjih nekoliko desetljeća, a njezine početke obilježila je knjiga G. Lakoffa i M. Johnsona (1980). Već je ta knjiga pokazala sveprisutnost konceptualne metafore, koja zrcali način mišljenja i samo posredno se odražava u jezičnim iskazima ili gestama. G. Lakoff i M. Johnson tumače metaforu kao shvaćanje jednoga pojma s pomoću drugoga pojma (Lakoff i Johnson 1980: 5), na temelju sličnosti između dviju domena, ciljne i polazne (jednosmjerno preslikavanje iz polazne u ciljnu domenu). Konceptualna metafora ne pokazuje istodobno sve aspekte određenih pojavnosti koje se dovode u odnos, nego ističe samo jedan. Određeni koncept može biti pokriven nizom konceptualnih metafora i metonimija (jedna ciljna domena može se tumačiti s više polaznih, ali moguće je da se jedna polazna domena preslikava na više ciljnih). U hrvatskoj znanosti prve radove iz toga područja napisala je Žic Fuchs (1991, 1992/1993). Nije potrebno ovdje sažimati što se sve u teoriji konceptualne metafore događalo u posljednjih nekoliko desetljeća jer je nedavno na hrvatskom jeziku dosege na tom području, iz svoje istraživačke pespektive, predstavio M.-M. Stanojević (2013). Moramo ovdje upozoriti, ipak, da treba strogo lučiti konceptualnu metaforu i metonimiju od metafore i metonimije kao jezičnih ukrasa u sklopu retorike i stilistike. Iz te potonje perspektive dosad se govorilo o metafori (i metonimiji) u analizama Gundulićeva baroknoga stila, njegova baroknoga ornatusa i "akutnoga" stila (osim u radovima D. Fališevac, v. npr. Pavličić 1979, Kravar 1997, Kravar 2003). 


\section{EMOCIJE U EPSKOM SVIJETU OSMANA I U DRAMSKOM SVIJETU OSMANŠĆICE}

2.0. Emocije su u svim književnim rodovima važne. Lirika je teško zamisliva bez emocija koje nam posreduje lirski subjekt. U epici i drami emocije su važni pokretači radnje, i to tako da su emocijama zaokupljeni određeni akteri u drami, a u epici zahvaćaju i čitave kolektive.

Teško bi se moglo izdvojiti pjevanje Osmana koje nije na neki način barem djelomice emocionalno obojeno, bez obzira na to je li riječ o naraciji o Hoćimskom boju, Osmanovu svrgnuću s vlasti i ubojstvu ili je riječ o umetnutim epizodama o zaljubljenim ratnicama Sokolici i Krunoslavi, ugrabljenoj ljepotici Sunčanici te nekim drugim sporednim likovima (npr. ljubavni četverokut Korevski-Krunoslava-Kalinka-Ljubica ili ljubav Dilavera i Begum Adžamkinje). Iz upravo navedenoga mogao bi se steći dojam da će u žarištu zanimanja u ovom prilogu biti ljubav, ali u prvi istraživački plan postavljene su srdžba i strah.

2.1. Srdžba može biti vrlo zanimljiv predmet istraživanja književnoga teksta zato što se uvijek postavlja pitanje kako se pisac i pripovjedač određuju prema toj emociji koja se u kršćanskom svijetu smatra smrtnim grijehom (ako je povezana s činjenjem zla). ${ }^{9}$ Stoga nije svojstvena kršćanskim junacima u epskim književnim djelima (tabuizirana je) i najčešće se stereotipno pridaje protivnicima. Tako ni kršćanska pravednica Suzana u istoimenom Marulićevu epiliju nije prikazana u srdžbi (za razliku od kršćanskoga puka kao kolektiva), nego se njezina emocionalna uznemirenost očituje kao tuga, što je izraženo plakanjem i uzdisanjem (Kapetanović 2006: 24). Dukić iznosi slična zapažanja prilikom proučavanja antiturske hrvatske epike XVI. stoljeća: "Srdžba je uvijek shvaćena kao legitimno oružje onostranog autoriteta i kao ljudski grijeh, a time i kao atribut koji je zamisliv samo za drugu stranu, za protivnika, za Oni-tabor. I ta se ljudska srdžba može katkad zamisliti kao posredni izraz božanske srdžbe [...]" (Dukić 2012: 237).

9 Nijanse se nerijetko gube, pa se svaki oblik srdžbe može smatrati grijehom. Tako je srdžba u književnosti tabuizirana emocija u vezi s kršćanskim junacima o kojima se govori iz kršćanske perspektive. Da je riječ o pojednostavnjenim tumačenjima srdžbe, v. u Bibliji npr. Ef 4,26. O srdžbi kao grijehu v. i u Grmača 2010: 256-257. 
2.1.1. U petom pjevanju Osmana daje se opis boja između turske ratnice Sokolice i poljske ratnice Krunoslave. Pripovjedač kazuje pritom da su obje pune srdžbe, koja, začinjena čemerom, stvara zvuk sličan vjetru sjevercu što zimi prolazi kroz drveće:

\section{Pune srdžbe i čemera one u sebi buče time, jak na vihru od sjevera dubje u gori posred zime (Gundulić 1964: 63).}

Drugim riječima, srdžba začinjena čemerom prikazuje se kao uzburkani sadržaj spremnika (= 'ljudskoga tijela'), na što upućuju riječi pun, u sebi buče. Ovdje se u jezičnoj uporabi zrcali konceptualna metafora SRDŽBA JE SADRŽAJ U SPREMNIKU. ${ }^{10}$ Nije nevažno napomenuti da je Krunoslava kao predstavnica kršćanske strane prikazana također kao osoba koja je ispunjena srdžbom, ali stotinu i pedeset stihova prije navedenoga iskaza atributom "plemenita" opravdana je srdžba kršćanske ratnice:
Začu mlada i protiva hudoj sreći srce utvrdi, s plemenita tere gniva prijeti osvete, tužbe grdi (Gundulić 1964: 59).

2.1.2. Sokoličina srdžba slično se opisuje i na drugom mjestu u epu (kada se bori protiv Vladislava i njegove pratnje koja dolazi na rijeku gdje se Sokolica sa svojim ratnicama kupala):
Jakno tigre, zvijer srdita, iz planinske kadno spile lovac skupi i pohita porode joj drage i mile, pune bijesa i čemera u plahom se krši tijeku, i zlotvora dočim tjera, reži u ognju strašnu i prijeku;

10 Za većinu ovdje razmatranih konceptualnih metafora primjeri se iz drugih jezičnih korpusa i dodatna teorijska objašnjenja mogu naći u Kövecsesovim radovima (npr. Kövecses 2000, 2003, 2010). 
tako puna srčbe ognjene

i ohola bojnica je,

čim u plijenu zaplijenjene

oslobodit druge haje.

(Gundulić 1964: 125).

Sokolica se na tom mjestu uspoređuje s divljom (srditom) zvijeri (tigrom) i opet se pritom govori o ispunjenosti bijesom i čemerom, odnosno srdžbom ognjenom. Iz toga potonjega jasno se može uočiti da se srdžba povezuje s toplinom koja je pohranjena u spremniku (metafora SRDŽBA JE VRUĆ SADRŽAJ U SPREMNIKU). U Osmanu se u jezičnoj uporabi ne razotkriva poima li se (uobičajeno) taj vruć sadržaj kao plin ili tekućina, međutim takvo poimanje dolazi do izražaja u Mrnavićevoj Osmanšćici, odnosno povezuju se uskiptjeli otrovi sa srdžbom, a srdžba u potocima teče ili se prolijeva u replici Tališmana:

Usilni jadovi gdi sad uzkipiše,

Smućene otrovi gdi se uzgnjiviše,

Gdi novi uzroci smutnje podbadaju,

Saržbeni potoci gdi puk podžigaju,

Bojim se uzmožno da ni puk vladati

Ni vojstvo primožno zakonom skladati

I da jur livade i ravne poljane

Ćute gorke jade, ćute smartne rane,

Da puci smeteni jur gnjiv prolivaju,

Vojnici splašeni da sva prodiraju.

Mučno je goruću dubravu gasiti,

Mučnije tekuću riku uzstaviti

(Marnavich 1631: 107).

Kada se govori o pobuni u 17. pjevanju Osmana, uzbunjeni puk prispodobljuje se valovitu i zapjenjenu moru, a srdžba se pripisuje čitavu puku:

Jak ne dmjenje od sjevera

kad zapjeni sinje more,

sila silu dočim tjera,

vali uzrastu kako gore,

tako uzbuča vas puk oni

na besjede age verna;

teku, srnu svi smioni,

puni gnjeva neizmerna

(Gundulić 1964: 245). 


\subsubsection{Odmah potom kaže se:}

S golom sabljom u desnici skaču u bijesu nesvijesnomu

(Gundulić 1964: 245).

Taj primjer zrcali jedno drukčije poimanje srdžbe, koje je najlakše sažeti konceptualnom metaforom SRDŽBA JE SPREMNIK (detektira se najlakše po uporabi prijedloga koji označuju intralokalnost, npr. $u$ ). Takvi iskazi potvrđeni su na nekoliko mjesta u Osmanu, na primjer kada je riječ o borbi Derviša, o Sokolici ili pri kraju epa o pobunjenicima:

Ori sablju on i u gnivu

Imbrahimu desnu odsiječe

(Gundulić 1964: 280).

Ovo izrekši van ismuca

svijem veliku jednu gredu

i, na udorac da nje puca

mir, navali š njom $\mathbf{u}$ ijedu ${ }^{11}$

(Gundulić 1964: 277).

A i toliko ona je lijepa

i u rasrdžbi i u gnjivu

(Gundulić 1964: 126).

U ovoj bijesti izvan sebe

udarajuć na sve strane

(Gundulić 1964: 311).

U Mrnavićevoj Osmanšćici nema puno mjesta na kojima se zrcale dvije prethodno oprimjerene konceptualne metafore utemeljene na predodžbenoj shemi spremnika. Prvu (SRDŽBA JE SPREMNIK) potvrđuje prijedlog srid uz riječ sard (= 'srdžba'), a druga (SRDŽBA JE SADRŽAJ U SPREMNIKU) se zrcali u vezi glagola provaliti i imenice sardce (koje je u ovom slučaju, kao tjelesni organ, spremnik za emociju srdžbe):

Živu i živeći srid sarda smart nose

(Marnavich 1631: 137),

11 U primarnom značenju (i)jed označuje otrov, a u izvedenim (metaforičkim) značenjima ljutinu, bijes, srdžbu. U Osmanu su potvrđena oba značenja. 
Saržbu provališe sardcem ražaljenim

(Marnavich 1631: 51).

U Mrnavićevu tekstu naći ćemo odraz konceptualne metonimije, koja se temelji na povezivanju rumenila na licu, osobine (sarditosti) i glagola snapati (= 'izlaziti, prodirati'):

Kroz rumeno lice sarditost snapaše (Marnavich 1631: 102).

2.1.4. Vidjeli smo već da se srdžba dovodi u vezu s toplinom (vrućim sadržajem u spremniku), a s tim poimanjem dodiruje se i ono poimanje srdžbe koje se može sažeti konceptualnom metaforom SRDŽBA JE VATRA:

Nad svijem vječnijem sjenam stišten

strašnodržac od propasti

gnjevnom srdžbom vas zaprišten [= 'raspaljen, zažaren']

planta [= 'plamti'] u zlobnoj oholasti

(Gundulić 1964: 187).

Sij omraze, zlobe budi, srdžbe užiži, vriježi gnjive...

(Gundulić 1964: 192).

Svak se uzbuni, svak razgnivi;

posta žamor, pače sva se

vojska užeže u plam živi

u strašive vapeć glase

(Gundulić 1964: 273).

Ta se metafora zrcali ne samo u stihovima u kojima se donose zaključci iz pakla i opisuje se pakleni car (Gundulić ga naziva i tvrdoglavim bijesnikom, opisuje ga sa zanimljivim ponašajnim i tjelesnim očitovanjima, npr. usne grizuć s ijeda mnoga, Gundulić 1964: 187) nego i u ocrtavanju osmanlijske vojske. Osobito se ističe prikaz srdžbe urotnika Dauta, zeta majke svrgnutoga Mustafe, koja se postupno pojačava sve do "nesvijesnoga" bijesa, a povezuje se s vatrom i njezinim uzročnicima (vjetar, grom) i zapaljivim sadržajem, što se riga zajedno s mržnjom iz spremnika (ovdje je to dio tijela: srca).

Jakno plahi sjever kada priko mraznijeh gora ulijeta

u dubravu listopada

u ku se oganj jur upreta, 
silno dmenje vihra bijesa

sve razgara i razdiže,

pali, prži, do nebesa

strahovite plame diže,

tako planu na riječi ove

otprije užežen Daut vrli

$[\ldots]$

Ko kad pukne grom, iz koga

s urnebesom trijesi udare,

omraze i gniv srca svoga

riga, izdajstva i privare.

Bez obzira srne kuda

nesvijesni ga bijes potiče,

i s pogleda srčna i huda

mećući oganj, vapeć kliče

(Gundulić 1964: 267, 270).

Na nekoliko mjesta u Mrnavićevoj Osmanšćici moguće je naći potvrdu poimanja srdžbe kao vatre, što se ovako odražava u leksiku:

Užga se razgnjivom saržbe jadovite

(Marnavich 1631: 49 $9^{12}$ ),

Razjadnom rasardom prema njih sjati se

(Marnavich 1631: 52).

2.1.5. Srdžba se u Osmanu poima i kao protivna sila koju se ne može ili ju treba obuzdati (SRDŽBA JE SILA), što se zrcali u opisu Kserksova pokušaja kroćenja mora (poima se kao da je u srdžbi) kao što se krote bijesne životinje (bijesne konje kroti i vlada, Gundulić 1964: 50):

Da li scijeniš tvojom vlasti

srdžbe ukrotit mora vrla?

(Gundulić 1964: 81).

I u Mrnavićevu tekstu moguće je naći potvrdu za takvo poimanje, ali je zanimljivo da se u Osmanšćici poima kao vatrena sila (što nekontrolirana vatra sigurno jest), a uporišta za tu tvrdnju nalazimo u odrazima u leksiku, i to u uporabi glagola zagasiti i vladati $(+\mathrm{A})$ :

12 U izvorniku je pogrešno otisnuta brojka kao oznaka stranice (stoji 51 umjesto 49). 


\section{Jeda se zagasi gnjiv koji jih vlada}

(Marnavich 1631:125).

2.1.6. Što se tiče srdžbe u Osmanu i Osmanšćici, može se reći da se poimanja, kada se leksikalizirana i nerijetko konvencionalna površina oljušti, ne razlikuju nimalo od današnjih što upućuje na njihovu stabilnost u vremenu. Posebno treba istaknuti leksičko bogatstvo vezano uz izražavanje srdžbe dovoljno je reći, izostavivši pritom brojne glagole i pridjeve, da se srdžba u ta dva teksta imenuje na desetak načina, i to u različitim oblicima (bijes, bijest, srdžba, gnjev, razgnjiv, sard, rasarda, rasrdžba, ijed). Emocija srdžbe u Osmanu dopuštena je samo neprijateljima kršćana, Osmanlijama, s iznimkom tzv. plemenita gnjeva ratnice Krunoslave. U Osmanšćici nema likova kršćana, a srditost Osmanlija, pa i Osmana, opisuje se bez zadrške.

2.2. Strah i zastrašenost obično nisu značajke kršćanskih junaka u hrvatskoj epici, pa je to emocionalno stanje, kao i srdžba, tabuizirano i proskribirano u naraciji o kršćanskim junacima u Osmanu. Analizirajući hrvatsku antitursku epiku XVI. stoljeća, Dukić iznosi još precizniji zaključak: "U dužim i ambicioznijim epskim djelima (Vetranović, Sasin, Pisam od Malte) uočava se tabuiranje vlastita straha [...]", ali “pjesnički produkti u kojima se zamjećuju propagandne funkcije i pučki stil [...] slobodnije manipuliraju strahom vlastite strane - on je logična posljedica ljudske/povijesne nepravde (protivnikove okrutnosti ili izdaje u vlastitom taboru) koju ne treba prešućivati [...]" (Dukić 2012: 237).

U Osmanu se emocija straha pridaje Osmanlijama i ugrabljenoj Sunčanici:

$\mathrm{Nu}$ što velim, care Osmane?

I ti poznaš isti opeta

da Vladislav zdrži obrane

od krstjanstva svega svijeta.

Samoga se njega bojiš,

od samoga njega predaš;

bez pokoja zato stojiš

(Gundulić 1964: 78).

Gorka je boles opet smeta, opet zavrć riječ ne može; priuze teški strah ju opeta i opet se prinemože

(Gundulić 1964: 109). 
2.2.1. Mrnavić u svojoj uvodnoj posveti rođaku F. K. Mrnaviću govori o kolektivnom turskom strahu:

[...] i slišah i dobar dil gledah čudne zgode prikonaravske, koje se zgodiše u to doba po turačkih daržavah velikim strahom i smetenjem svega puka njihova [...] I tako složiv jih imenom Osmanšćice, naminih trud moj pismeni rajnomu otcu tvojemu, a stricu mojemu; koji dokole živi, vridnostju razuma gospodskoga i hrabrenstvom desnice vitečske takov strah biše ugnal u daržave i narode turačke [...] (Marnavich 1631: 3)

Tako se kolektivni strah predstavlja i u dramskom tekstu (npr. u razgovoru Jusufa i Režepa u 2. šinici 1. stvora):

Rež[ep]. [...] Tim se zastrašiše svi turski narodi

Jer čudo vidiše ko se pri ne zgodi.

Jus[uf]. Čudnovato čudo i ko mene straši,

Kime svako udo strašno se nasarši.

Ukloni Bog kobi kom ta oganj priti,

Od takove zlobi nas ov vik zašćiti.

Rež[ep]. Ak t' je nevično što si dosad sliša

I strahu prilično kim se čemer miša,

Što ću t' sad kazovat, sve strahe nadhodi

(Marnavich 1631: 30-31).

Međutim kršćanskoj vojsci u bitci kod Hoćima, iako je ispričana iz osmanlijske perpektive (jasan je odnos oni : naši), ne pridaje se na epski način strašljivost i ne uskraćuje se snaga i hrabrost protivnicima:

Lehi pošteno juriš izčekaše

I Turkom hrabreno dobar razlog daše,

Jer što god snažnije naši nasartahu,

Oni hrabrenije naših odbijahu

(Marnavich 1631: 49).

2.2.2. I u jednom i u drugom tekstu strah se prikazuje kao oblik represije:

zašto, zasveda turački

strah je i rasap naša sila,

kraljević je svud poljački

štiti i obrana lijepijeh vila

(Gundulić 1964: 128), 
Pravi učitelji robskoga nauka,

Hitri svršitelji, jesu strah, bič, muka

(Marnavich 1631: 25),

Za carskim magnutćem znadeš da svak miga,

Za njiha ganutćem svaku vuhla smiga.

Sada, kad gledaju stvari zlo spravljene,

Kad strahom predaju, jur svi hvale mene

(Marnavich 1631: 36).

2.2.3. U oba teksta nalazimo opise fizioloških reakcija ljudi koji su u strahu i fizičku eksteriorizaciju straha. Primjerice pripovjedač u Osmanu ovako opisuje reakcije Sunčanice:

\section{Sunčanica sprva od straha učini se mrazna stijena, blijeda, nijema, bez uzdaha, iščeznuta, zapanjena}

(Gundulić 1964: 108).

2.2.4. Bitno je zapaziti povezivanje uplašene Sunčanice s hladnom stijenom, što je blisko metonimijskoj osnovi poimanja STRAH JE HLADNOĆA (metonimijsko je zato što se spuštanje temperature tijela zamjenjuje sa strahom što je fiziološka reakcija tijela osobe u strahu). No osim osjećaja hladnoće tu je i nepomičnost (stijena, bez uzdaha), bljedilo (blijeda), nijemost (nijema) i odsutnost (ǐ̌čeznuta, zapanjena). Neuobičajene su Mrnavićeve potvrde poimanja straha kao vatre, što je suprotno navedenim povezivanjima straha i hladnoće:

Strahom zasnićeni, neznanjem darhćući

(Marnavich 1631: 34),

Svi strasi pakleni da me će znobiti

(Marnavich 1631: 23).

U Osmanšćici se predočavaju i druge reakcije na strah (ježenje, groženje, drhtanje):

Čutit ćeš strahotu kom se samom jižiš

(Marnavich 1631: 24),

Strahota gloziše, strahota tamašna

(Marnavich 1631: 54), 
Od straha je darhtat mneć da ga klat htihu

(Marnavich 1631: 156).

Posebno se ističe opis uplašena Osmana kad shvaća da nema izlaza, i to tako da se opisuje nestanak njegova rumenila koje zamjenjuje bljedilo, razni pokreti tijela (spuštena glava, sklapanje očiju, traženje čvrstoga oslonca i grčenje tijela, potom uzdisanje i puštanje promukla glasa):

Rodno mu pobiže tudje rumenilo,

A smartno ga stiže po licu blidilo.

I glavu prikloni, i oči poklopi,

$\mathrm{Na}$ zid se nasloni, tilom se vas sklopi.

Malo popostavši, uzdahnu uzdahom

Pak reče pušćavši glasi muklim strahom

(Marnavich 1631: 169).

2.2.5. U obama tekstovima nalaze se iskazi u kojima se odražava konceptualna metafora STRAH JE TERET. U Osmanu nalazimo naprimjer atribut teški uz riječ strah:

priuze teški strah ju opeta i opet se prinemože

(Gundulić 1964: 109).

To je još očitije u Osmanšćici, u iskazima o dizanju straha i o tome kako se nešto nalazi pod strahom:

Strahe nastojaše dvignut svih tišeći

Pod silom, pod strahom, pod čudom svakome

(Marnavich 1631: 46).

2.2.6. Povezivanje straha i sile (STRAH JE SILA) očituje se u Mrnavićevu tekstu u iskazima kako strah vlada mnoštvom ili kako je strah ozlijedio srca:

Strah množiju vlada i množiju hini

(Marnavich 1631: 35),

Poplaha neznana svih sardca ranila

(Marnavich 1631: 46).

Razvidno je iz prethodnoga primjera povezivanje srca sa strahom: 
Tad jim vas strah veće od sardca otide

(Marnavich 1631: 53),

svačija srca čeznu od straha

(Gundulić 1964: 64).

2.2.7. I na koncu, treba istaknuti poimanje straha kao spremnika (STRAH JE SPREMNIK) i kao sadržaja u spremniku (STRAH JE SADRŽAJ SPREMNIKA):

U strahu velomu tač Turci budući

(Marnavich 1631: 57),

hitra kuna, zec pun straha

(Gundulić 1964: 123).

Analiza straha mogla bi poteći i u kapilarne interpretacije, ali glavninu smo bitnih poimanja straha u oba teksta spomenuli i oprimjerili. Mrnavićev tekst ukazuje na to da i u drami, kao i u antiturskoj epici, "tuga često zamjenjuje 'nedopuštenu' srdžbu i 'nelagodni' strah" (Dukić 2012: 237):

Ali strah žalostju barzo se zamini

(Marnavich 1631: 46).

Navedeni primjeri za strah upućuju na to da strah oba pisca isto konceptualiziraju - a na isti način moguće je i danas - jedino od ubičajenih poimanja odudara Mrnavićevo poimanje straha kao vatre (obično se povezuje s hladnoćom).

2.3. U nastavku ćemo fokus istraživanja premjestiti na još dvije osnovne emocije, tugu i radost.

2.3.1. I tuga i radost poimaju se u oba teksta uz pomoć predodžbene sheme spremnika, odnosno nalazimo u njima odraze konceptualnih metafora: TUGA JE SADRŽAJ SPREMNIKA i TUGA JE SPREMNIK; RADOST JE SADRŽAJ SPREMNIKA, RADOST JE SPREMNIK.

$\mathrm{Nu}$ u veselju općenomu

(Gundulić 1964: 171),

Koji se pokoje u mirnoj radosti

(Marnavich 1631: 131), 
U žalosti i u bolesti

(Gundulić 1964: 105),

Vazda s' u žalosti, sad ob njoj ne tlapi

(Marnavich 1631: 25),

Ču kraljević glas pun sreće

(Gundulić 1964: 136),

Ner srid radovanja mirnoga plivamo

(Marnavich 1631: 95),

kliče starac pun žalosti

(Gundulić 1964: 102),

Tuge otrovane da ne bi rignule

(Marnavich 1631: 81).

Prva su četiri primjera jasna jer u svima njima na emociju kao spremnik upućuje isti prijedlog $u$. Sreća u primjeru iz Osmana u tom kontekstu ima značenje radost, a pridjev pun, kao i uz žalost u pretposljednjem primjeru, upućuje na to da se obje emocije shvaćaju i kao sadržaj spremnika. Preostala dva primjera, u kojima se spominje radovanje i glagol rignuti pomalo se razliku od ostalih primjera. Kad je riječ o primjeru u kojem se spominje radovanje, tu nisu razvidne granice spremnika, nego je samo radovanje spremnik što se poima kao tekućina (srid, miran, plivati). U posljednjem, Mrnavićevu primjeru upotrijebljen je glagol rignuti koji iskazuje istjecanje ili izbacivanje tuge iz spremnika. Tuga se pritom poima kao otrov(a)na tekućina, što je razvidno i iz ovoga Mrnavićeva primjera, u kojem se spominje istjecanje (kiptjeti) zapjenjene otrovane tuge:

Kipeć pinom živom tuge otrovite

(Marnavich 1631: 49).

2.3.2. Tuga se doživljava i kao bolest (TUGA JE BOLEST), a prati ju otrov koji razara srce:

ali ne znam ču li ikada

koliko je privelika

boles ka mi srce jada

$\mathrm{s}$ ropstva draga vjerenika

(Gundulić 1964: 66). 
2.3.3. Osim toga tuga se doživljava kao sila ili protivnik (TUGA JE SILA) koja obuzima ili podbada:

Hož i vezire, ki svitom vladaše

Žalosti bez mire danas obujaše

(Marnavich 1631: 140),

Jer smućeno množtvo, ko žalost podbada

(Marnavich 1631: 76).

2.3.4. S obzirom na to da se radosti i žalosti kadšto pridaju atributi za ljudska bića i radnje koje obavljaju ljudi (zloufana, dostojna, prihiniti [= 'prevariti']), takvi personificirajući iskazi odraz su konceptualnih metafora TUGA JE OSOBA i RADOST JE OSOBA.

Zloufana radost da se kad promini,

Da dostojna žalost radosti prihini

(Marnavich 1631: 22).

2.3.5. Radost (sreća) poima se i kao biljka (glagol sijati).

Ali je taj srića u ritko sijana

(Marnavich 1631: 92).

2.4. Romantična ljubav i mržnja ne ubrajaju se u osnovne emocije, ali bez njihova odraza teško je naći epski ili dramski tekst. Osmanšćica je zasigurno iznimka zato što u njoj ne nalazimo ljubavne zaplete i romantičnu ljubav, ali se ljubav u Osmanu provlači kroz niz pjevanja i odnosa među likovima.

2.4.1. Najprvo treba reći da 9. pjevanje Osmana otpočinje apostrofom Ljubavi, koju se tako personificira (LJUBAV JE OSOBA) i utjelovljuje ju Amor, bog ljubavi, te se spominjanjem vatrenih strijela priziva poimanje ljubavi kao rata (LJUBAV JE RAT):

Velika se, o Ljubavi,

vlas ognjenih tvojijeh strijela

u pogledu lijepom slavi

oka draga i vesela

(Gundulić 1964: 112).

Na jednom drugom mjestu u Osmanu, prilikom susreta Kalinke i Krunoslave, to se i eksplicira: 


\begin{abstract}
Ah, zaisto zno je vele taj ki u stara doba stavi zlatan trkač, luk i strijele bogu ognjenom od ljubavi; er na svijetu nije toga mjesta otajna i skrovita gdi iz luka ljuvenoga zlatna strijela ne dohita. Ljubav ima zlatna pera, zlatan je i plam kim sve užiže; zlatnijem krilim ona tjera i bjeguća srca stiže. Ljubav ima zlatna pera, zlatan je i plam kim sve užiže; zlatnijem krilim ona tjera i bjeguća srca stiže.
\end{abstract}

(Gundulić 1964: 174).

2.4.2. Metafora LJUBAV JE RAT odražava se i u ovom odlomku, kada se opisuje odnos cara i Sokolice:

On s pogleda nje sunčana,

kijem ga iz oči lijepih strijelja,

primi i pozna veće rana

negli od svijeh neprijatelja

(Gundulić 1964: 51).

Na te stihove nadovezuju se oni u kojima se ljubav poima kao vatra (LJUBAV JE VATRA):

Vas mlađahan plam je ognjeni

s druge, rajske nje lipote,

ka pozorim svijetlijem plijeni

svačija srca i živote.

(Gundulić 1964: 51).

2.4.3. U nastavku se daju stihovi u kojima se zrcali konceptualna metafora LJUBAV JE SUŽANJSTVO (glagol robovati) i kombinira se s metaforom LJUBAV JE ČAROLIJA (glagol traviti [= 'čarati']):

Nu robujuć u ljubavi car se otkriti ne usudi 
lijepoj ka mu dušu travi

što u srcu svomu žudi

(Gundulić 1964: 51).

2.4.4. Obostrani ljubavni osjećaji prikazuju se uz pomoć već spomenute metafore LJUBAV JE VATRA:

Zasve da ga ognji živi

zatvoreni huđe prže,

čezne da ju ne razgnivi

i od sve vojske ne odvrže.

Ali i za njim Sokolica

i ne manjijem ognjem gori;

ljuven pogled s draga lica

i nje tvrdo srce otvori

(Gundulić 1964: 51).

2.4.5. U Gundulićevim stihovima ogleda se i metafora LJUBAV JE SADRŽAJ SPREMNIKA:

čestit, miran, pun ljubavi,

s tri ljubovce lijepe uza se

(Gundulić 1964: 247).

2.4.6. Mržnja se, za razliku od drugih emocija, teško može izolirati u dvama tekstovima, odnosno teško ju je razlučiti od drugih emocija, osobito kada djeluje kao snažnija srdžba, primjerice u opisu Krunoslave u Osmanu:

Ukazat ću Krunoslava

u osvetah kakva biva:

usred zmaja, usred lava,

usred ognja da je živa [...]

Užežena ja sva gorim,

čijem druzijeh spražit hajem

(Gundulić 1964: 181, 182).

Ako se to mjesto protumači kao mržnja (kojoj je podloga osveta), onda se mržnja poima kao vatra (MRŽNJA JE VATRA).

2.4.7. U leksiku tih dvaju tekstova mržnja je zastupljena imenicom omraza. U Osmanu nalazimo potvrdu za poimanje mržnje kao tereta (MRŽNJA JE TERET), što se ponajviše očituje u pridjevu težak: 
Ter s podsmijehom, u kom smeću

i omrazu tešku ukaza

(Gundulić 1964: 264).

2.4.8. Poimanje mržnje kao biljke (MRŽNJA JE BILJKA) odražava se u primjeru u kojem se govori o sijanju ${ }^{13}$ :

Sij omraze, zlobe budi

(Gundulić 1964: 192).

2.4.9. Naposljetku i mržnja se jednako kao i srdžba riga iz srca, što upućuje na poimanje mržnje kao sadržaja spremnika (MRŽNJA JE SADRŽAJ SPREMNIKA):

Ko kad pukne grom, iz koga

s urnebesom trijesi udare, omraze i gniv srca svoga riga, izdavstva i privare

(Gundulić 1964: 270).

\section{ZAKLJUČAK}

U ovom prilogu nastojali smo, osim iznošenja nalaza, primijeniti iskustvo stečeno u bavljenju teorijom konceptualne metafore na književnopovijesni opis s ciljem da se oljušte u leksičkim i iskaznim konvencijama zakrivena dubinska, kulturno specifična ili (gotovo) univerzalna poimanja emocija. Cilj rada nije bio daljnje razvijanje teorije konceptualne metafore.

Ovdje provedena komparativna analiza pokazala je kako emocije prožimaju oba teksta iz prve polovice baroknoga stoljeća, Gundulićev ep i Mrnavićevu dramu o Osmanu II. Iskazivanje emocija ima svoju funkciju u gradnji epske i dramske radnje. Srdžba kršćana tabuizirana je u Gundulićevu Osmanu jer pripovjedač zbivanja prikazuje iz kršćanske perspektive (pojednostavnjeno se svaki oblik srdžbe smatra grijehom), dok takvih zadrški nema u Mrnavićevu tekstu koji događaje prikazuje iz muslimanske perspektive.

13 V. i alegoričan početak 1. šinice 4. stvora: Sime ko sijasmo lišo je izniknulo, / Busje ko plijasmo već se je ubusilo... / Građane s vojnici varlo nabrusismo... 
Postoji razlika između dvaju tekstova i u iskazivanju straha jer Gundulić ne želi govoriti o strahu kršćanskih junaka, dok Mrnavićevi junaci (primjerice Jusuf i Režep u 2. šinici 2. stvora) ne skrivaju osmanlijske gubitke i nejunačke trenutke svojih boraca te snagu i hrabrost kršćanskih protivnika. Što se tiče ostalih emocija koje su osim srdžbe i straha ovdje uzete u obzir (tuga, radost, ljubav, mržnja), postoje razlike i u odrazima konceptualnih metafora i metonimija za te emocije (jedna od neobičnih razlika jest Mrnavićevo poimanje straha kao vatre i topline, dok Gundulić i mnogi drugi pisci od srednjega vijeka do danas povezuju strah i hladnoću). Romantične ljubavi u Mrnavićevoj drami uopće nema, pa je to bitna razlika u odnosu na Gundulićev ep. Postoje i druge manje razlike (npr. dok je Gundulić preferirao jednu, Mrnavić je preferirao neku drugu metaforu za određenu emociju). Osim toga utvrđena su i mnoga poklapanja i istosti među piscima kada je riječ o emocijama i uglavnom je riječ o poimanjima koja su (gotovo) univerzalna kao što je slučaj s konceptualnim metaforama što se temelje na predodžbenoj shemi spremnika (npr. poimanje emocija kao spremnika i kao sadržaja u spremniku).

\section{LITERATURA}

Dukić, Davor. 2004. Jedan povod za dva pogleda iznutra - Gundulićev Osman i Mrnavićeva Osmanšćica, u: Sultanova djeca. Predodžbe Turaka u hrvatskoj književnosti ranog novovjekovlja. Zadar: Thema i.d.

Dukić, Davor. 2012. Iščitavanje srdžbe i straha u hrvatskoj antiturskoj epici XVI. stoljeća, u: Poj željno! Iskazivanje i poimanje emocija u hrvatskoj pisanoj kulturi srednjega i ranoga novoga vijeka, ur. A. Kapetanović. Zagreb: Institut za hrvatski jezik i jezikoslovlje, 217-242.

Ekman, Paul i Wallace V. Friesen. 1986. A new pan-cultural facial expression of emotion. "Motivation and Emotion" 10, 159-168.

Ekman, Paul. 1970. Universal facial expressions of emotions. "California Mental Health Digest" 8/7, 151-158.

Fališevac, Dunja. 1997. Kompozicija i epski svijet Osmana (iz vizure naratologije), u: Kaliopin vrt. Split: Književni krug, 139-160.

Fališevac, Dunja. 2003. Shvaćanje povijesti u Mrnavićevoj Osmanšćici i Gundulićevu Osmanu, u: Kaliopin vrt II. Split: Književni krug, 27-47.

Fališevac, Dunja. ${ }^{2} 2007$. Gundulićev Osman kao epski model u hrvatskoj epici 17. i 18. stoljeća, u: Stari pisci hrvatski i njihove poetike. Zagreb: Hrvatska sveučilišna naklada, 229-243.

Fancev, Franjo. 1933/1934. Fragment dosad nepoznate epske pjesme Osman. "Nastavni vjesnik” XLII/8-10, 237-249. 
Grmača, Dolores. 2010. Držićevi grijesi u tri prizora, u: Marin Držić 1508.-2008. Zbornik radova s međunarodnoga znanstvenog skupa održanog 5.-7. studenoga 2008. u Zagrebu. Zagreb: HAZU, 247-277.

Gundulić, Ivan. ${ }^{2}$ 1964. Osman. Pet stoljeća hrvatske književnosti 13/2. Zagreb: Matica hrvatska - Zora.

Kapetanović, Amir. 2006. Leksik Marulićeve Suzane. "Colloquia Maruliana” XV, 15-25.

Kapetanović, Amir. 2008. Pitanje dijalekatske osnovice Mrnavićeve Osmanšćice. "Croatica et Slavica Iadertina" 4, 89-104.

Kapetanović, Amir. 2009. Pojmovne metafore za emocije u Ranjininu zborniku. "Rad HAZU" 502, 109-121.

Kapetanović, Amir. 2012. Otisci tijela u umu i govoru: emocije u Marulićevoj epici, u: Poj željno! Iskazivanje i poimanje emocija u hrvatskoj pisanoj kulturi srednjega $i$ ranoga novoga vijeka, ur. A. Kapetanović. Zagreb: Institut za hrvatski jezik i jezikoslovlje, 187-215.

Kapetanović, Amir. 2013. Searching for hidden ancient containers in the Old Croatian language: the body and emotions as containers. "Suvremena lingvistika" 39/76, 127-143.

Kövecses, Zoltán. 2000. Metaphor and Emotions: Emotions, Culture, and Body in Human Feeling. Cambridge: Cambridge University Press.

Kövecses, Zoltan. 2003. Metaphor And Emotion: Language, Culture, and Body in Human Feeling. Cambridge: Cambridge University Press.

Kövecses, Zoltan. 2010. Metaphor: A Practical Introduction. Oxford: Oxford University Press.

Kravar, Zoran. 1993. Svjetovi Osmana, u: Nakon godine MDC: studije o književnom baroku i dodirnim temama. Dubrovnik: Matica hrvatska Ogranak Dubrovnik, 104-125.

Kravar, Zoran. 2003. Jedan dijeljeno s tri: Acutezza u Bunića, Gundulića i Đurđevića. Hrvatska književna baština 2. Zagreb: Ex libris, 417-449.

Kukuljević Sakcinski, Ivan. 1868. Ivan Tomko Marnavić, “Arkiv za povjestnicu jugoslavensku" IX, 242-265.

Lakoff, George i Mark Johnson. 1980. Metaphors We Live By. Chicago - London: The University of Chicago Press.

Marnavich, Ivan Tomko. 1631. Osmanschica. Rim : Pri Yakovu Maskardu.

Novak, Slobodan Prosperov. 1999. Povijest hrvatske književnosti. Od Gundulićeva poroda od tmine do Kačićeva Razgovora ugodnog[a] naroda slovinskoga iz 1756. III. Knjiga. Zagreb: Izdanja Antibarbarus.

Pavić, Armin. 1875. Ivan Tomko Mrnavić. "Rad JAZU” 33, 58-127.

Pavličić, Pavao. 1979. Rasprave o hrvatskoj baroknoj književnosti. Split: Čakavski sabor.

Pavličić, Pavao. 1996. Studije o Osmanu. Zagreb: Zavod za znanost o književnosti Filozofskoga fakulteta.

Petz, Boris. 2003. Uvod u psihologiju. Psihologija za nepsihologe. II. izdanje. Jastrebarsko: Naklada Slap.

Petz, Boris (ur.). ${ }^{2} 2005$. Psihologijski rječnik (autori I. Furlan, S. Kljaić, V. Kolesarić, M. Krizmanić, B. Petz, S. Szabo, B. Šverko). Jastrebarsko: Naklada Slap. 
Rapacka, Joanna. 1998. Tankred u Carigradu, u: Zaljubljeni u vilu. Split: Književni krug, 137-163. [ $\left.{ }^{1} 1975.\right]$

Rosenwein, Barbara. 2006. Emotional communities in the early Middle Ages. Ithaca London: Cornell University Press.

Rosenwein, Barbara. 2016. Generations of feelings. A History of Emotions, 600-1700. Cambridge: Cambridge University Press.

Scherer, Klaus R. 2003. Uvod u socijalnu psihologiju, ur. M. Hewstone, W. Stroebe. Zagreb: Naklada Slap.

Stanojević, Mateusz-Milan. 2013. Konceptualna metafora. Temeljni pojmovi, teorijski pristupi i metode. Zagreb: Srednja Europa.

Tatarin, Milovan. 2015. Dva sultana: Osman i Mustafa. "Hrvatska revija” 2/2015, 93-95.

Vukoja, Vida. 2012. Dobro i zlo - dva lica ljubavi (Značenjska raščlamba hrvatskih crkvenoslavenskih leksema osnova izvedenih iz korijena ljub-), u: Poj željno! Iskazivanje i poimanje emocija u hrvatskoj pisanoj kulturi srednjega i novoga vijeka, ur. A. Kapetanović. Zagreb: Institut za hrvatski jezik i jezikoslovlje, 25-85.

Wierzbicka, Anna. 1999. Emotions Across Languages and Cultures. Diversity and Universals. Cambridge: Cambridge University Press.

Žic Fuchs, Milena. 1991. Metafora kao odraz kulture, u: Prožimanje kultura i jezika, ur. M. Andrijašević i Y. Vrhovac. Zagreb: HDPL, 27-33.

Žic Fuchs, Milena. 1992/1993. Konvencionalne i pjesničke metafore. "Filologija" 20/ 21, 585-593.

\section{SUMMARY \\ THE EMOTIONAL WORLD OF OSMAN AND OSMANŠ́́ICA}

The paper describes and compares portrayals and conceptions of some "basic" emotions in Gundulić's Osman and Mrnavić's Osmanšćica, two Croatian literary works from the Baroque period which describe the life, rule, and death of the Ottoman sultan Osman II. Emotions play a vital role in both dramatic and epic worlds of these texts. Special attention is paid to the connection of emotional discourse with particular metaphorical concepts (rage, fear, sadness, joy, love, and hate), stereotypical conceptions and conventional vocabulary, taking into account the differences in perspective between the two authors (Gundulić's Christian perspective and Mrnavić's Ottoman perspective), which result in specific differences in the description of emotions.

Keywords: emotions, Ivan Gundulić, Ivan Tomko Mrnavić, Osman II, epic, drama, Croatian language and literature, $17^{\text {th }}$ century 